\title{
SAYED ABDUL MUTALLAB MOUSSAWI AND ITS CULTURAL AND POLITICAL IMPACT IN THE DISTRICT OF ESSAOUIRA $(1923$ - 2004)
}

\author{
*M. Dr. Mahdi Hashim Mohammed Al Mamouri, ** Dr. MowaffaqHadi Salem Defense \\ *Wasit University / College of Basic Education \\ **Diyala University / College of Education for Humanities
}

DOI: $10.37648 / \mathrm{ijrssh.v10i01.032}$

Received:24 ${ }^{\text {th }}$ October 2019; Accepted:30th November, 2019; Published:17 $7^{\text {th }}$ December, 2019

\section{ABSTRACT}

Mr. AbdAlmuttalibAlmousawi (1923-2004): is an important characters to sons of sowirah for his intellectual, cultural and literary institution, and not to forget hi political role on the scope of his city expressing to how his love to his country generally and his city especially, so we should as an academic researchers to document about this character.

\section{INTRODUCTION}

Historical studies have overlooked many figures that were not highlighted, since they did not have a presence on the political stage despite their national presence and stemmed from their sense of moral and religious affiliation to the soil of this dear country, and therefore did not have a significant impact on the internal and external level of their countries, or their impact The effects of the study remain limited, waiting for the researchers' pens to investigate and discuss what is useful, especially since the study of history has been added to know the problems and hypotheses that the study of any subject and then draw conclusions to complete the optimal use in the study of history.

The personality of Sayyed Abdul mutallab alMusawi has a great presence in the city of Essaouira, leaving us with a significant heritage in the literary and cultural aspects, as well as being a social and religious figure, and to study this character must be put some hypotheses to be answered between the folds of this study, namely:

1 - what the reasons that made Sayed Abdul Muttalib to be a prominent place among the sons of his hometown of Essaouira.

2 - Malalth left by Sayed Abdul Muttalib to lead the list of personalities that influenced his society, especially his city of Essaouira.

3 - How was able to Abdul Sayed Abdul Muttalib access to the science of literature and authorship, although he does not hold an academic degree.

4 - What national motives that made him political and did not belong, which prompted him to support some of the principles of political parties, which paid the price in his imprisonment in political prisons and prisons. 
The study included the introduction of four axes and some conclusions. The fourth axis focused on the cultural and literary activity, which included the literature he wrote, and the literary and cultural activity of the people of the city of Essaouira.

The researcher was able to obtain only a few sources, including personal interviews of his contemporaries and some of his books. Some of them were printed and the other part is still a manuscript.

\section{THE FIRST AXIS: HIS BIRTH AND UPBRINGING AND PERSONALITY FEATURES}

He is Mr. Abdul Muttalib bin Hashem bin Mohammed bin Ibrahim bin Ismail bin Khalil bin Habib bin Ahmed bin Mohammed bin Aqil bin Muslim bin Mohammed bin Hashem bin Ali bin Hassan bin Hussein bin Ahmed bin Murtada bin Talib bin Mohammed bin Taj al-Din bin Sharaf al-Din bin Hussein Ghali bin Sadr al-Din bin Nizam al-Din bin Mahmoud bin Jamal al-Din bin Mahmoud bin Sadr alDin bin Mahmoud bin Shihab al-Din bin al-Sharif Abdullah al-Awklani bin Imam Musa bin Jaafar (peace be upon him $)^{(1)}$.

He was born in the district of Kemit, Adaria district of Amara (Maysan) on the 26th of February 1923.His family moved to the city of Essaouira, which is still forty days old and remained for a short period and returned again to the district of Kemet. He arrived in the fifth stage of primary school, but he left school in 1935 and devoted himself to work in buying and selling ${ }^{(2)}$. He is still small ${ }^{(3)}$.

In 1939, Sayyed Abdul mutallab and his family moved to the city of Essaouira to take him as his residence. His family, represented by his grandfather, Mohammed Al-Qara'i, became famous in Essaouira for belonging to the Hashemite family. The reader who was elected as a deputy in the Iraqi parliament at the time ${ }^{(4)}$.

Mr. Abdul mutallab was invited to serve science on January 5, 1942 and was discharged from the army on February 1, 1947.He returned to practice his buying and selling business .He opened a shop for aromatics and herbal medicine until he became his main profession. After he became authorized by the official authorities in the practice of this profession, which was inherited by his children later, and his shop is still located in the great market of Essaouira ${ }^{(5)}$.

Mr. Abdul Muttalib was married after three males and four daughters. The guard guarded them to raise them and take care of them to the fullest. Some of them received academic certificates. His elder son, Mr. Asaad, became an agricultural engineer, while his son, Mr. Nasser, was a teacher. Literature in Arabic ${ }^{(6)}$.

Mr. Abdul mutallab was a meek, beautiful, kind, humble, humorous, companion, and a travel companion. He was interesting in his blending of honesty and kindness ${ }^{(7)}$.

He grew up in the midst of a religious family that practiced and still practiced the religious duties and rituals of Husseini. He became one of the elders of this family. Far from radicalization and advocates of reform to carry out an intellectual renaissance in all areas, despite his modest achievement, he had a clear vision for the advancement of his city and his country and at all levels of cultural, intellectual, social, national and economic $^{(8)}$.

\section{THE SECOND AXIS: ITS SOCIAL AND CULTURAL IMPACT.}

Since Mr. Abdul Muttalib from the family of Alawite Moses, he had a great impact among the people of his hometown of Essaouira became one of the most prominent flags of the city, and took people to resort to him in solving social problems and some legitimate issues that he can solve, including the marriage and the reform of the same Advice or advice felt useful to the general public, and was meeting in his large and small and rich and poor and educated or educated and uneducated and the son of the city and the son of the countryside, that his work in herbal medicine has earned him good relations with his fans, especially as he used herbs and the Koran in the treatment of patients, which was traded Formally Bear at the time ${ }^{(9)}$ 
Mr. Abdul mutallab was not a politician but was a patriot and a supporter of the republican system in Iraq, but it must be said that religious references in the fifties of the last century do not encourage the engagement of politics and belonging to parties, but that Mr. Abdul mutallab was a supporter of the revolution Abdul Karim Qasim, 14 July 1958. It must be said that Sayyed Abdul mutallab has become a store of social information belonging to his hometown of Essaouira and neighboring areas, because of the reluctance of people to place his work to hold the Koran or the growing demand for medicinal herbs, which earned him skill and experience in his work and social relations ${ }^{(10) .}$

\section{THE THIRD AXIS: ITS NATIONAL IMPACT AND POLITICAL ORIENTATIONS.}

As for the patriotism of Sayyed Abdul mutallab and his political orientation, he was in love with his country, his nation and the colonialist. He was not a member of any political party or party. In the 1960s, he was accused of belonging to the Communist Party because of his participation in the popular demonstrations in support of the July 14, 1958 revolution. He was jailed during the National Guard era and sentenced to three years in prison by the martial court headed by Shaker Mahmoud Masoud, of which he spent six months and was released pardoned (11) by Abdul Salam Aref when he came to power in Iraq after his destruction of the National Guard in $1963^{(12)}$.

Sayyed Abdul-Muttalib continued his national approach through poems he delivered at national and religious occasions calling for combating colonialism, supporting the Palestinian cause and calling for the unity of his country. On the other hand, he devoted part of his love and loyalty to his hometown of Kumit. He grew up in it, he said in his love for Kumit ${ }^{(13)}$ :

hey blame me that I loved ruins of a dying land

Kumit by my family and Azi and my brothers and the level of my body and bear by Zafari
Sayyid Abdul Muttalib wanted to give us a clear picture of his attachment to his city where he was raised and gave him something that he and his family members to raise what he learned in this city to a wider and world, especially in the literary and social aspects.

\section{THE FOURTH AXIS: ITS LITERARY AND CULTURAL IMPACT.}

SayyedAbdulmutallab acquired his culture from the environment in which he grew up, especially his home, represented by his father SayyidHashim and his grandfather, Sayyid Muhammad, who have a great influence in refining his literary and social talents as well as the religious aspects that he grew up from. And written some of the historical events of the city of Essaouira and his books (poets of Essaouira and its artists), which was printed in 1968 three parts, and the book (Essaouira past and present) in three parts, also authored Abdul Muttalib series of books, which are still manuscript of which (the history of Essaouira) and (our customs) And (like us) and ( Islam as I knew it) (14)

This cultural and literary treasury was written by Sayed Abdelmutallab in his humble shop to sell herbs. To express it through his compositions.

He started writing his first book (poets and artists of Essaouira) in the first months of 1968, and noted that the city of Essaouira deserves this achievement as it includes a selection of the finest poets, sculptors, painters and calligraphers as well as playwrights, actors, athletes, journalists and others, so he had to show This elite to the world of fame to get to know their communities for what they have multiple talents, this showed us by Sayed Abdul mutallab through his author, which divided it into three parts, the first part, which came with (167) page of the poets of the reader, including KhairiHindawi who left us Varied lattice effects, Here has to be a historical reference to the incident was the Hindawi where verses of poetry, when the first post office in Essaouira was founded in 1913, which was Abdul-Aziz Al-Kassab ${ }^{(16)}$ district officer at the time of Essaouira was a charity Hindawi wrote verses of poetry which he says: 
Established a lightning line in our diameter who is immune to HE Hariz

O student symbol of its effects, which reveal the symbols

Suffice it to symbolize its history of lightning from the effects of Abdul Aziz

Sayyed Abdul Muttalib was able to collect the effects of the poet KhairiHindawi, including (silo tents) and (I and the Elder) and (Ya Rose Rose) and (defense of women) and (remembrance and reproach) and other poetry ${ }^{(17)}$.

Among the other poets included in the book Sayed Abdul Muttalib is the poet Khalil Hanoun al-Saadi, whose poetry is characterized by realism away from fiction, from his poetic products (Shahid al-Tuff), which he wrote in 1967 and other works including (Crow on Doha), which expressed his mockery of pretenders of poetry The book also includes another poet, Kazem Haji Alaiwi, who wrote several poems, including (from the past), and other poems (with dawn), (justice of the universe), (words directed), (repel and meet) and (beautiful dream The last poem represents the life of a man who has divided his age to diamonds and sorrows and to a free life with beautiful meanings. The morning of Haji Alioui has provided us with poetic works no less important for those who preceded it emerged the historical aspect of the nation of Islam through his poetry came poem entitled (O nation of Islam do not hesitate), while influenced by the poet Ali GhalibHindawi uncle poet KhairiHindawi, also included the book (poets Essaouira and its artists) The poetic effects of his author Sayed Abdulmutallab, including the poem he gave in 1967 to the Governor of the Kut Brigade (Mr. Mohsen Al-Refaie), the beginning of which is:

God is greater than the treachery of the bands and the scum of scum

She collaborated on us and is his world that what I asked in the fantasies ${ }^{(18)}$.
It is a long poem delivered on the occasion of fundraising to support the armed forces fighting for the Palestinian cause.

For his loyalty and love of education, Mr. Abdul Muttalib wrote a poem on the occasion of the 50th anniversary of the founding of the Essaouira Primary School for Boys:

he cradle of science fiftieth day showed all my emotions and nostalgia

In the thread of fulfillment a necklace dedicated to each teacher was organized

This poem contains dozens of verses of poetry, and there is another poem known as the poem (nostalgia) written when he visited his hometown city (dungeon) twenty-seven years after her departure, we mention part of it:

To the land of architecture, my knees find walking for hours

In the town of Kumit, I left a flight, and the wind was lost

I remembered childhood as a cradle not perfect and has attributed an example

The tears have gone down on Ghawali and days spent ignorant and money

There are other religious poems written by Sayed Abdul Muttalib, including a poem entitled (Sharia Muhammadiyah) and the number of verses (340) beta, some of which we show:

Good, there is a magnificence and building, and it is a green paradise

And Tdouan fragrant revived irrigation filled almost fatigue

Sayyid 'Abd al-Muttalib also recited his poetic book with another poem about the birth of Imam Hassan (as) Its title (the first tribe) says at the beginning: 
Gospel of goodness to the house of the Prophet good and then Zaki

I was happy with his light Fatim as it resembles the light of the Prophet

And Hashim Ala our God and lost the fragrance argument shining

And yathrib Senna bright and love that Senna class

This poem to praise the Prophet included the verses of about twenty-six verses of the birth of the first tribe (peace be upon him).

Sayyed Abdul Muttalib did not drop the curtain on his first author, but continued to put forward the traces of other poets, including Abdul Hussein Kamel AlAjili, who was associated with Sayyid Abdul Muttalib in his life, including his poetic literature on love and spinning, as well as individual space for a good writer Majid Younis Hajj Jawad, which included many articles published In the newspaper Al-Ittihad alBaghdadiya to its owner Naji al-Qashtini ${ }^{(19)}$ in 1939, as was the young poet Naseer Hassan has a share of the book Sayed Abdul Muttalib I and this poet from the city of Essaouira and has poems in modern poetry, including a poem entitled (Monologues) written in Baghdad in 1966, and the last thing In the first book the products of the poet Sadiq al-Adhari, who wrote several poems, including a poem entitled (AL-ssaouira) (20).

The second part of the book of poets of Essaouira and its artists, has included a group of popular poets are (Abdul Mahdi Khayat, Yarub dish, Khudair Abbas AlMerhej, Karim Al-Hadi, Sheikh Samarmad al-Hamad, Musafir ibn Mutlaq, Fadaabint Ali Al-Sweih, Mullah advantage, Jaber al-Ansari, Mr. Ibrahim al-Sayyid Ali al-Musawi, Abdul Muttalib al-Musawi, Abdul Hussein Kamel al-Ajili, SadiqKazem al-Rashid, SihoudNayef). The book was (208) pages. The third part came with (96) pages about the artistic movement in Essaouira, represented by artists, including Jihad Kazem AlShaikhli, who graduated in the cradle of fine arts, Department of Fine Arts in 1961 and was apprenticed by the artist Faeq Hassan ${ }^{(21)}$. Other artists mentioned by SayyedAbdulmutallab in his third part are: JalilMazhar Al-Taie, graduate of the Institute of Fine Arts, Department of Fine Arts in 1964; The most prominent in the district of EssaouiraZakiKhalafHamawandi, and a number of other representatives, including Faisal Saleh Dabbaj graduated from the Institute of Fine Arts Acting Department of 1964-1965 and Daoud Salman al-Taie graduate of the Academy of Fine Arts Department of Performing Arts in 1966-1967 and successor ShawkiDaoudi ${ }^{(22)}$, who had a large share From the book of Sayed Abdul Muttal Part III The activity of Sayed Abdul Muttalib was not limited to poetry and popular poetry, but included the side of stories, was the first Abdul Sayed Muttalib storytellers and has anecdotal works including (authorized) and (crazy) as well as other writers wrote in this aspect, including Mahdi Saleh Taie and Abbas KazimAjili ${ }^{(23) .}$

Among the other effects left by Mr. Abdul Muttalib his other book (Essaouira past and present) with its three parts, the first part carried several topics with a number of pages (103) page included the city of Essaouira and the date of its founding and ancient site and name and buildings and houses and administrative and health and social status and agricultural situation of its regions, and mentioned Sayyed Abdul Muttalib said that the city of Essaouira was founded in 1852 and was not officially recognized until 1884 and remained administratively linked to Baghdad until 1927, after it was annexed to the province of Wasit and stated that Essaouira was called old in Essaire, a place for members of the gendarme during the reign of the Ottoman Sultan Abdul Majeed Khan, who took power for 1939-1861, is best known for this name ${ }^{(24)}$.

The second part (88 pages), Mr. Abdul Muttalib focused on the inhabitants of Essaouira and administrative divisions of the regions of Essaouira and its effects, trade and education in Essaouira, political trends and national awareness, and the incidents experienced by Essaouira during the last century, including the fire of the market in Essaouira in 1912 and drowning Essaouira in $1946^{(25)}$. 
The subjects of the disadvantages left by the Ottoman and British occupation in Essaouira and the customs and traditions of the Arab tribes in the city of Essaouira and the religious shrines in Essaouira, including the shrine of Imam Tajuddin (peace be upon him) were all part III of the book Sayed Abdul Muttalib sequence pages (84) pages ${ }^{(26) \text {. }}$

Thus, it can be considered that Mr. Abdul mutallab Moussaoui was the first to date to spend Essaouira, given the title of historian of Essaouiragrand ${ }^{(27)}$.

Mr. Abdul mutallab had written manuscripts that had not been seen yet and had not been obtained by his family $^{(28)}$, including the history of al-Zubaydiyah district and the history of al-'Aziziyyah district. Which contained Iraqi heritage and folklore ${ }^{(29)}$.

It is interesting to note that Sayed Abdel Mottaleb was one of the witnesses to the land donation issue given by the leader Abdel Karim Kassem to build a school in the city of Essaouira. 1960 in the Tabou district of ALssaouira $^{(30)}$.

Sayyed Abdul Muttalib al-Moussawi died at the age of $81^{(31)}$, leaving behind a modest cultural and literary legacy ${ }^{(32)}$.

Yamousseau emerged as religion, literature, art, science, history and Arabs

Son of the delicacies and Sadat, their notaries over the world forever, neither falsely

This takes care of what tells the sweetest talking line of gold

Your travel book for generations AtfahYabnEssaouira past tastes sweet

And tamed Deirtk smoked him shattered winds from his lighter era

\section{CONCLUSIONS:}

By studying this character and verifying in its details we have come to several conclusions as follows:
1 - Sayed Abdul Muttalib is one of the personalities who wrote themselves a community presence.

2 - Alawite descent and religious upbringing made him a character characterized by a prominent position among the members of his community.

3 - the emergence of the national sentiment of Mr. Abdul Muttalib and his stand by the national movements that call for the unity of the country and preserve the dignity and national belonging.

4 - Mr. Abdul Muttalib proved that the academic certificate alone is not enough to embrace the cultural, literary and intellectual aspects, but there is a talent and will enable the individual to get his desired.

5 - Manuscripts and printed literature of Mr. Abdul Muttalib gave us a cultural heritage of the city of Essaouira.

\section{MARGINS:}

1 - Personal interview with Mr. Ali, the youngest son of Mr. Abdul Muttalib at his home in the district of Essaouira on 28/12/2017

2 - The tribe of Al-Azrej is attributed to the tribe of Hamir, the tribes of JuhaishZubaydiya and their name is due to their great-grandfather AzraqShami, displaced from Najd and inhabited Iraq. .

3 - Sayed Abdul MuttalibSayyed Hashem, poets and artists of Essaouira, Part I, Haidariya printing press, Najaf Ashraf, 1968, p. 103.

4- Hamid al-Mutba'i, Encyclopedia of Flags and Scholars of Iraq, Part I, Al-Zaman International Organization for Press, Publication and Information, Baghdad, 2011, p. 522.

5 - Mr. Abdul Muttalib, the previous source, p. 103.

6 - personal interview with Sayed Ali in his home in Essaouira on 18/12/2017 
7 - personal interview with the poet and playwright, Abdul Hussein KamelAjili in his home in Essaouira on 24/12/2017.

8 - personal interview with Jalil Hassoun Assi in his home in Essaouira on 24/12/2017

9 - Interview with the retired teacher Abbas Harsin Jawad at his home in Essaouira on 24/12/2017

10 - personal interview with Abdul Hussein Kazem AlAjili in his home in Essaouira on 24/12/2017

11 - Adapted from the military court in Camp Rashid on 30/11/1963, and 2, p. 2. Seen Appendix number one.

12 - personal interview with Abdul Hussein Kazem AlAjili in his home in Essaouira on 24/12/2017.

13. The same source.

14- Sayed Abdul Muttalib, previous source, p. 104.

15 - personal interview with Abbas Harsin Jawad at his home in Essaouira on 24/12/2017.

16- He was born in Baghdad in 1888 and was called Qassab because his grandfather had slaughtered a lot of sheep and camels during the circumcision of his children. He called him villagers in Qassab. He completed his preliminary studies in Istanbul in 1905. Then, in 1926, he served as the Minister of Interior and then became a deputy in the parliament and his chairman. He served as Minister of Irrigation and Justice and died in 1965. See: Hamid al-Mutba'i, ibid., P. 498.

17- Sayed Abdul Muttalib, previous source, part I, pp. $15-24$

\section{The same source}

19-Naji al-Qashtini was born in Baghdad in 1899. He was a poet and educator who was educated by his uncle Sheikh Abbas Hilmi al-Qassab.He published his first poem in 1916 in Al-Zuhur newspaper. He was one of the pioneers of his printed books (Eid Al-Nahda) which was printed in 1923 in Baghdad. Eyes of poetry) in
1968 and wrote about several personalities, including Rafael Butti, Yousef Izz al-Din, Abdullah al-Jubouri and KourkisAwad; see: Hamid al-Mutba'i, the previous source, p. 795.

20- Sayed Abdul mutallab, previous source, part II, pp. 130-140.

21 - plastic artist born in Baghdad in 1914 graduated from the French School of Fine Arts in 1935, was appointed a teacher in the House of Teachers high in 1948, founded with the artist HakkiShibli Institute of Fine Arts, was an experienced professor at the Faculty of Fine Arts University of Baghdad, died world 1991. Details seen: Hamid al-Mutba'i, ibid., P. 90.

22 - Journalist and critic born in 1898 fluent in French, German, English, Hindi and Farsi as well as Arabic, issued the magazine Shatt al-Arab in Basra in 1923 worked to unify the dialects of the Kurdish language in the framework of a unified Kurdish language, with many articles in the newspaper Al-Baghdad times and moderation magazine Najafi and teachers died 1939. For more details see: Hamid al-Mutba'i, ibid., P. 233.

23- Sayed Abdel-Muttalib, previous source, part III, pp. 30-45.

24- Abdul Muttalib, Essaouira, Past and Present, Part I, Anwar Printing Press, Baghdad, 2001.

25 - Sayed Abdel-Muttalib, Essaouira, its past and present, c 2 .

26. Sayed Abdel-Muttalib, Essaouira Past and Present, Part III.

27- In appreciation of the cultural, intellectual, social and political efforts of Mr. Abdulmutallab Al-Musawi, the President of Wasit University, Prof. Dr. HadiDuwaij Al-Atabi was approached during his visit to the Faculty of Information in the district of Essaouira on February 19, 2019 by one of its employees called (Hadi Abu Hassan Al-Khadrawi) and Dr. historian Mahdi Hashem Mohammed Al-Maamouri approved the launching of the name of $\mathrm{Mr}$. Abdulmutallab Al-Moussawi on the conference hall of the college and actually got the approval and was 
included in the recommendations of the visit. Mahdi to submit a study in this regard, but it was rejected by the dean of the college d. For more information, see the official study submitted by Dr. Mehdi Hashim Mohammed al-Maamouri to the Deanship of the Faculty of Information in the district of Essaouira on February 24, 2019.

28- Born in Baghdad in 1937, Bassem Abdul Hamid graduated from the Faculty of Education / History Department in 1960. He is a critic and folk researcher with a large presence in international conferences until 1968.He became the editor of the popular heritage magazine in 1985. He has many books, including the third face of Iraqi women. For more information, see: Hamid al-Mutba'i, ibid., P. 89.

29- Personal interview with Sayed Ali in a circuit in Essaouira on 4/1/2018 b. The abdication by the leader Abdul Karim Qasim to the Iraqi Ministry of Finance in the Department of TabuEssaouira on 29/6/1960.

30- Interview with Sayed Ali at his home in Essaouira on $4 / 1 / 2018$.

31- The document of the piece numbered 2/1/1 looks at Kout / Essaouira / Hosseini, according to the concession by the leader Abdul Karim Qasim to the Iraqi Ministry of Finance in the Tabu Department of Essaouira on 29/6/1960.

32 - a poem by the poet Latif JumaBawi of the people of Essaouira inherit the Sayed Abdul Muttalib after his death. 